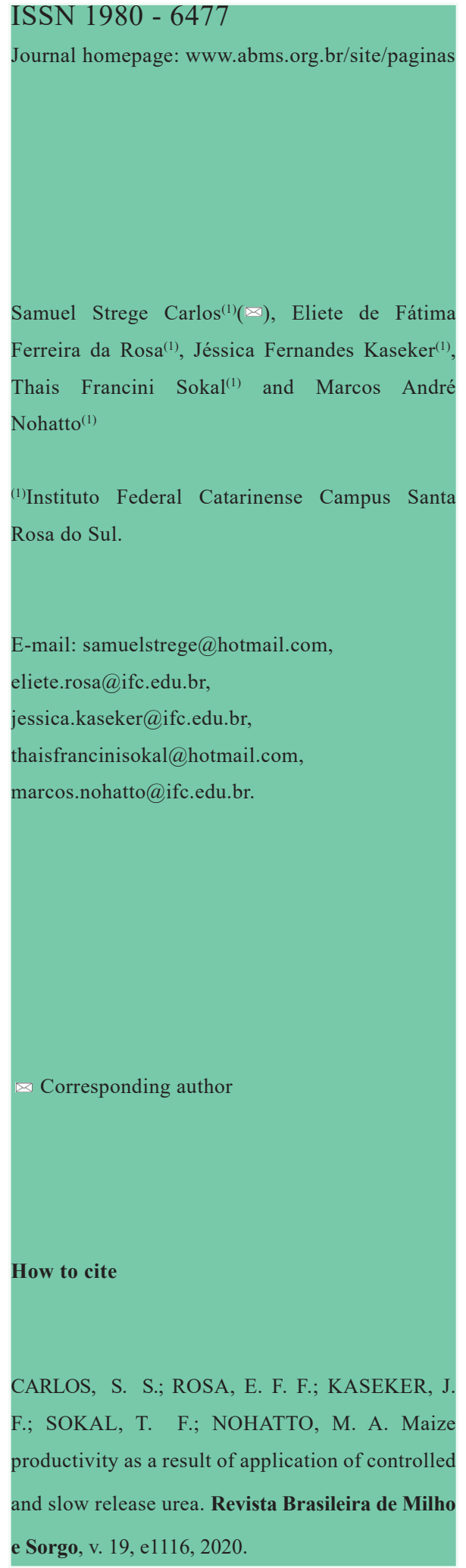

\section{MAIZE PRODUCTIVITY AS A RESULT OF APPLICATION OF CONTROLLED AND SLOW RELEASE UREA}

\begin{abstract}
Nitrogen $(\mathrm{N})$ is the main limiting nutrient for productivity and yield components of maize crop. Urea is the main nitrogen source used, which, despite the high $\mathrm{N}$ concentration (45\%), presents many losses through leaching and volatilization. In view of that, the purpose of the experiment was to evaluate the effect of applying $\mathrm{N}$ doses with urease inhibitor, nitrification inhibitor and slow-release urea, in relation to the conventional urea, on productivity and yield components of maize crop. The experiment was conducted in the municipality of Santa Rosa do Sul, state of Santa Catarina, in a $4 \times 5$ factorial scheme, where factor A corresponded to four nitrogen protection mechanisms (urea with urease inhibitor, urea with nitrification inhibitor, slow-release urea and conventional urea) and factor B corresponded to the surfaceapplied nitrogen percentage for the aforementioned protection mechanisms $(0 \%$, $25 \%, 50 \%, 75 \%$ and $100 \%$ ). Under the edaphoclimatic conditions of the present study, fertilizers with inhibitors (nitrification and urease) and with slow release do not significantly increase maize productivity in relation to the conventional urea and, regardless of the source used, it is possible to reduce the recommended dose by $25 \%$, based on soil analysis, without significantly impacting maize productivity.
\end{abstract}

Keywords: Nitrogen, dicyandiamide, NBPT, polymer-coated urea, Zea mays.

\section{PRODUTIVIDADE DO MILHO EM FUNÇÃO DA APLICAÇÃO DE UREIAS DE LIBERAÇÃO CONTROLADA E LENTA}

\begin{abstract}
Resumo - O Nitrogênio $(\mathrm{N})$ é o principal nutriente limitante de produtividade e componentes de rendimento da cultura do milho. A principal fonte nitrogenada utilizada é a ureia que, apesar da grande concentração de $\mathrm{N}(45 \%)$, apresenta muitas perdas por lixiviação e volatilização. Diante disso, o experimento teve como objetivo avaliar o efeito da aplicação de doses de $\mathrm{N}$ com inibidor de urease, inibidor de nitrificação e ureia de liberação lenta, em relação a ureia convencional, nos componentes de rendimento e produtividade da cultura do milho. O experimento foi conduzido em Santa Rosa do Sul, SC, em esquema fatorial 4x5, sendo o fator A composto de quatro formas de proteção de nitrogênio (ureia com inibidor de urease, ureia com inibidor de nitrificação, ureia de liberação lenta e ureia convencional) e o fator B porcentagem de $\mathrm{N}$ aplicado em cobertura das referidas formas de proteção $(0 \%, 25 \%, 50 \%, 75 \%$ e $100 \%$ ). Nas condições edafoclimáticas do presente estudo, os fertilizantes com inibidores (nitrificação e urease) e de liberação lenta não aumentam significativamente a produtividade de milho em relação à ureia convencional e, independentemente da fonte utilizada, é possível reduzir a dose recomendada em $25 \%$, com base na análise de solo, sem afetar significativamente a produtividade de milho.
\end{abstract}

Palavras-chave: Nitrogênio, dicianodiamida, NBPT, ureia com polímeros, Zea mays. 
The maize (Zea mays) crop is regarded as one of the largest crops in Brazil, being largely used for both human and animal consumption, among other factors due to the high nutritional value of their grains (Guareschi et al., 2013). Nitrogen $(\mathrm{N})$ is the main limiting nutrient for productivity and yield components of maize crops, thus influencing most of their growth and development characteristics (Mota et al., 2015). Since nitrogen is the nutrient that presents the most significant effects on increase of grain yield (Soratto et al., 2011), high productivity is reached with high doses of nitrogen fertilizers.

The main source of nitrogen is urea, which is the most used $\mathrm{N}$ fertilizer in agriculture worldwide, with a progressive tendency to remain as the main nitrogen fertilizer due to its low price and high $\mathrm{N}$ concentration. It is also the most used nitrogen fertilizer in Brazil, since it presents a good combination of agronomic efficiency and price in relation to the other nitrogen fertilizers (Mota et al., 2015). However, when applied to the soil surface, it is subject to high $\mathrm{N}$ losses due to leaching, volatilization and denitrification, with only around $44 \%$ of $\mathrm{N}$ being available and absorbed by the plants, thus reducing the fertilization efficiency (Soratto et al., 2011; Guareschi et al., 2013; Silva, et al., 2017; Lima et al., 2018). In view of that, new technologies are being tested to minimize those losses.

Losses of ammonia $\left(\mathrm{NH}_{3}\right)$ due to volatilization can be reduced with the use of inhibitors, such as urease, added to the urea with the purpose to delay its hydrolysis. Among the products available, the NBPT (N-(n-butyl) thiophosphoric triamide) is the most relevant. This inhibitor makes the product up to $50 \%$ less volatile in comparison with the conventional urea, being capable of delaying the volatilization peak for up to four days, thus providing a longer uptake period for the plants and leading to cumulative $\mathrm{N}$ losses that are up to $75 \%$ lower (Lana et al., 2018; Lima et al., 2018). Hence, the use of this technology can increase crop yield, as observed for oat (Gans et al., 2006), but may also have no effect on fertilization efficiency and yield, as observed for maize (Mota et al., 2015). The response depends on the edaphoclimatic conditions and the crop, being higher in conditions where high losses of $\mathrm{NH}_{3}$ by volatilization are expected, such as in alkaline soil, although not limited to this condition (Abalos et al., 2014).

Another alternative to increase fertilization efficiency is the use of nitrification inhibitors with the purpose to delay the nitrate $\left(\mathrm{NO}_{3}^{-}\right)$formation in the soil by the interference in the activity of the bacteria of the genus Nitrosomonas, which are responsible for the oxidation of ammonium $\left(\mathrm{NH}_{4}^{+}\right)$to nitrite $\left(\mathrm{NO}_{2}^{-}\right)$(Moro et al., 2013). In the market, there are few nitrification inhibitors that present good results. One of them is the dicyandiamide (DCD), a nitrification inhibitor that presents increment of productivity in several crops, in particular when associated with the application of organic fertilizers, by delaying the process for up to ten weeks (Aita et al., 2013).

After conducting studies with nitrification inhibitors for 13 years in the USA, Malzer et al. 
(1989) concluded that the best results are found in sandy soil. When added to urea, the DCD achieved the best results. In an experiment to assess the use of nitrification inhibitor (DCD) and urease inhibitor (NBPT), the authors verified an increment in maize productivity of 7.5 and 12.5\%, respectively (Abalos et al., 2014). However, the authors state that such results are highly influenced by the soil texture and the cropping system.

Currently, polymer-coated or encapsulated nitrogen fertilizers can be found in the market. They have lower cost in relation to urease and nitrification inhibitors. The capsule is solubilized gradually to release the fertilizer, with the presence of a physical barrier between the nutrient and the external environment, which allows the reduction of $\mathrm{N}$ losses that frequently occur when urea is surface-applied (Civardi et al., 2011).

A study conducted with the purpose to assess the maize performance in no-tillage system, as a result of coated urea application, showed increase in the thousand grain weight, ear length and total maize yield in relation to the conventional urea (Guareschi et al., 2013).

In view of the above, the objective of the present study was to evaluate the effect of applying doses of nitrogen with urease inhibitor, nitrification inhibitor, and slow-release urea in relation to conventional urea, on yield components and productivity of maize crop.

\section{Material and Methods}

The work was carried out in the maize summer crop in the 2017/2018 agricultural year, in the experimental area for annual crops of the Federal Institute - IFC, Campus of Santa Rosa do Sul, located in the municipality of Santa Rosa do Sul, Santa Catarina. The climate in the region is classified as $\mathrm{Cfa}$, humid subtropical mesothermal climate, with well-defined summer and winter, and annual precipitation above 1,000 $\mathrm{mm}$, according to the Köppen climate classification. The soil in the area is classified as dystrophic Red Argisol. Daily precipitation and temperature during the period when the experiment was conducted are shown in Figure 1.

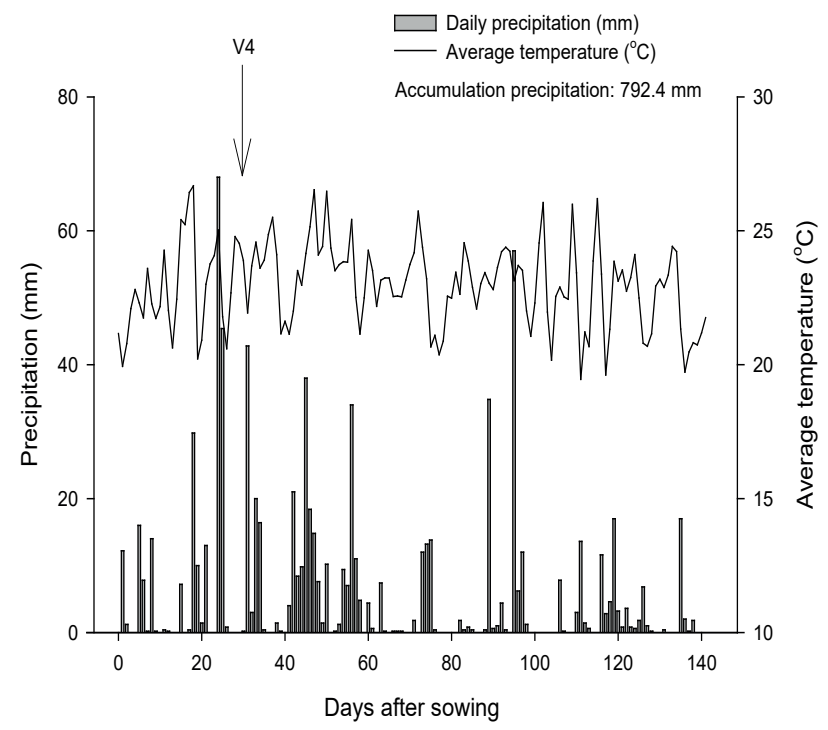

Figure 1. Daily and cumulative precipitation values and average temperature recorded during the period when the experiment was conducted (from $29 \mathrm{Nov}$ 2017 until 19 Apr 2018) in the experimental station of EPAGRI Araranguá - SC

The randomized block experimental design was used, with three replications, in a $4 \times 5$ factorial scheme, where factor A corresponded to 
four nitrogen protection mechanisms (urea with urease inhibitor, urea with nitrification inhibitor, slow-release urea and conventional urea) and factor B corresponded to the surface-applied nitrogen percentage for the aforementioned protection mechanisms $(0 \%, 25 \%, 50 \%, 75 \%$ and $100 \%)$. Every plot measured $5.0 \mathrm{~m}$ of length per six sowing rows with $0.65 \mathrm{~m}$ interrow spacing, totaling $19.5 \mathrm{~m}^{2}$, targeting at a final population of 65,000 plants ha-1, with $5.85 \mathrm{~m}^{2}$ being the useful area, which corresponded to the two central rows of the plot.

Previous analysis was carried out for evaluation of soil chemical features and clay content (Table 1) at the $0-20 \mathrm{~cm}$ depth. The results were interpreted based on the liming and fertilization manual for the states of Rio Grande do Sul and Santa Catarina (CQFS, 2016), with yield potential of 6 to $8 \mathrm{tha}^{-1}$.

Basal fertilization with phosphorus $(150 \mathrm{~kg}$ $\mathrm{ha}^{-1}$ of $\mathrm{P}_{2} \mathrm{O}_{5}$ in the form of triple superphosphate), potassium $\left(50 \mathrm{~kg} \mathrm{ha}^{-1}\right.$ of $\mathrm{K}_{2} \mathrm{O}$ in the form of $\mathrm{KCl}$ ), and nitrogen $\left(34.2 \mathrm{~kg} \mathrm{ha}^{-1}\right.$ in the form of urea, equivalent to $30 \%$ of the total $\mathrm{N}$ dose recommended for maize crop) was the same in all evaluated treatments, according to the fertilization recommendation for values found in the chemical feature analysis (CQFS, 2016). The remaining part of nitrogen fertilization was surface-applied, according to the recommended dose, with $0 \%, 25 \%, 50 \%, 75 \%$ and $100 \%$ of the total $\mathrm{N}$ being used, and corresponding to $0.0 ; 19.7 ; 39.4 ; 59.1 ; 78.7 \mathrm{~kg} \mathrm{ha}^{-1}$, respectively. The option was to maintain the recommended dose as the maximum value applied, since the lower losses that occurred with the use of coated fertilizers would allow the use of lower doses, without impacting yield.

Maize seeds were sown on the $29^{\text {th }}$ of November 2017, in no-tillage system, under common oat (Avena sativa) straw covering. The cultivar used was the single-cross hybrid Agroeste 1551 Pro2, with super-early cycle, and technologies for resistance to caterpillar and glyphosate.

Nitrification (DCD) and urease (NBPT) inhibitors were mixed with the conventional urea, just before the application, in the ratio of $10 \%$ of the total $\mathrm{N}$ recommended, following the dose levels tested and recommended by Soares et

Table 1. Soil chemical features and clay content in the experimental area, in the $0-20 \mathrm{~cm}$ layer.

\begin{tabular}{|c|c|c|c|c|c|c|c|c|c|c|}
\hline \multirow{2}{*}{$\begin{array}{c}\mathrm{pH} \\
\mathrm{H}_{2} \mathrm{O}^{(1)}\end{array}$} & \multirow{2}{*}{$\begin{array}{c}\mathrm{pH} \\
\text { SMP }\end{array}$} & K & $\mathrm{P}$ & $\mathrm{Ca}$ & $\mathrm{Mg}$ & $\mathrm{Al}$ & $\mathrm{H}+\mathrm{Al}$ & $\mathrm{CEC}_{\mathrm{pH} 7.0}$ & OM & Clay \\
\hline & & \multicolumn{2}{|c|}{-----mg dm³---- } & \multicolumn{5}{|c|}{ - } & \multicolumn{2}{|c|}{----------\%------- } \\
\hline 6.7 & 7.3 & 64.9 & 35.9 & 6.7 & 5.4 & 0.0 & 1.1 & 15.6 & 5.0 & 7.5 \\
\hline
\end{tabular}

${ }^{(1)} \mathrm{pH}$ in water. $\mathrm{pH}$ measured after addition of SMP solution. $\mathrm{K}$ and $\mathrm{P}$ : Mehlich-1 extractor. $\mathrm{Ca}, \mathrm{Mg}$ and $\mathrm{Al}: \mathrm{KCl}$ extractor $1 \mathrm{~mol} \mathrm{~L}^{-1}$. $\mathrm{H}+\mathrm{Al}$ : calcium acetate extractor $0.5 \mathrm{~mol} \mathrm{~L}^{-1}$. $\mathrm{CEC}_{\mathrm{pH} 7.0}$ : cation exchange capacity at $\mathrm{pH}$ 7.0. OM: organic matter $=\mathrm{OC} \times 1.724$. 
al. (2012).

Surface-applied nitrogen fertilization was carried out in a single broadcast application during the V4/V5 phenological stage, as per Ritchie's scale (Ritchie et al., 1993), that is, when the plants had four to five fully expanded leaves.

Glyphosate herbicide was applied for weed control, in post-emergence period, with the use of a backpack sprayer. The control of leafcutter ants was also performed at the $14^{\text {th }}$ day after sowing, with the application of granular insecticide with fipronil $(0.01 \%)$.

Five plants in R1 stage, as per Ritchie's scale (Ritchie et al., 1993), were randomly selected for evaluation, within the useful area of each plot. The characteristics evaluated were ear insertion height, measured from soil surface up to main ear base with the stem; stem diameter, measured with a digital caliper at $0.2 \mathrm{~m}$ from the soil; and leaf chlorophyll content, measured with a portable electronic chlorophyll content meter (clorofiLOG CFL1030) in the diagnostic leaf located in the same stem node where the main ear of the plant is inserted (Mota et al., 2015).

Harvesting was done manually on the $19^{\text {th }}$ of April 2018, when the kernels presented approximately $22 \%$ of moisture. All ears from the two central rows, considered as useful plot area, were harvested. After that, all ears were evaluated in order to determine the following grain yield components: ear length, determined with the use of a millimeter ruler; ear diameter, assessed with the use of a digital caliper; number of rows per ear, obtained through the counting of rows; number of kernels per row, obtained through the counting of kernels on one row per ear (Civardi et al., 2011).

Grain yield evaluation was based on sampling from each plot, with the values converted to $\mathrm{ha}^{-1}$, being determined based on the thousand grain weight and expressed in the standard unit of $130 \mathrm{~g} \mathrm{~kg}^{-1}$. This method is used when experiments present a high number of plots (Frazão et al., 2014; Mota et al., 2015). The thousand grain weight was obtained by separating a 100-grain sample, then converted to $130 \mathrm{~g} \mathrm{~kg}^{-1}$ and multiplied by 10 . The number of kernels per ear was estimated by means of ratios between thousand grain weight, total grain weight, and the number of ears harvested in the useful area of each experimental unit (Mota et al., 2015).

Data were submitted to F-test $(p<0.05)$ and when significance was detected, data were then analyzed through Tukey's test to compare the means $(p<0.05)$, with the assistance of the statistical analysis program SISVAR - 5.6 version.

\section{Results and Discussion}

There was no interaction between the factors concerning any of the evaluated variables. Individually, the $\mathrm{N}$ doses modified leaf chlorophyll content, number of kernels per row, ear length, thousand grain weight, number of kernels per ear and productivity, while the different nitrogen protection mechanisms only 
interfered in productivity (Tables 2 and 3). Lack of response as to the applied protection mechanisms indicates that the amount of $\mathrm{N}$ absorbed until silking stage was similar (Mota et al., 2015).

The leaf chlorophyll content increased as a response to higher $\mathrm{N}$ doses applied (Table 2). The same result was observed by Mota et al. (2015), also with no impact of the protection mechanisms used. Taking into account the presence of the nutrient in the chlorophyll molecule, this parameter is a good indicator of $\mathrm{N}$ availability in the soil (Vargas et al., 2012; Valderrama et al., 2014), with the leaf $\mathrm{N}$ contents being deemed appropriate when the chlorophyll contents are around 58.0 in the R1 growth stage (Argenta et al., 2001). Therefore, it can be noted that leaf $\mathrm{N}$ contents are low in all treatments, which justifies the response to the increase of $\mathrm{N}$ doses. It is important to emphasize that, even in soils with high content of organic matter, which represents an important source of nitrogen for the plants, as in the case of the present study (Table 1), the available amount of the nutrient may not be enough for proper plant development.

Ear insertion height, stem diameter and ear diameter (Table 2) were not influenced by the protection mechanisms or doses applied, which was also observed in a study comparing the conventional urea and the slow-release urea (Valderrama et al., 2011). Since these are genetic factors, they are highly influenced by the cultivar used and little affected by soil fertility (Valderrama et al., 2014). Although the ear length also has genetic influence, predominantly, it was greater when $100 \%$ of the recommended $\mathrm{N}$ dose was surface-applied in comparison with the control treatment.

In the work carried out by Civardi et al. (2011), they also verified an increase of the ear length in response to the increment of $\mathrm{N}$ doses, regardless of the use of coated or conventional urea, while in the study of Guareschi et al. (2013), that component was greater in the treatments where coated urea was applied, though showing no difference in respect to the doses applied.

The yield components - thousand grain weight, number of kernels per row, and number of kernels per ear - were greater in the treatments that received $100 \%$ of the recommended $\mathrm{N}$ dose, in comparison with the control treatment (Table 3). The effect on these components can be a result of the increase in the chlorophyll content, leading to a higher photosynthetic rate, which then allowed the production of more grains and extension of the grain-filling period (Mota et al., 2015). This result demonstrates the relevance of suitable topdressing fertilization when the plant is differentiating these yield components, as well as the importance of the nutrient for proper development of ears and kernels (Souza et al., 2011).

Productivity increased from dose 0 to the highest doses (75 and 100\%) (Table 3). The results also indicate that it would be possible to apply $75 \%$ of the recommended dose without reducing productivity, since there was no significant difference in relation to the 
application of $100 \%$ of the dose. However, when assessing the absolute values, there is a reduction by almost $800 \mathrm{~kg} \mathrm{ha}^{-1}$ from one treatment to the other, which may be significant to the producer in view of the profitability of the area. Therefore, a study involving costs is necessary to indicate if the dose reduction is economically viable or not, in order to avoid financial losses due to such choice.

Although no changes were noted in yield components, the productivity was higher when conventional urea was used, in comparison with slow-release urea (Table 3). Such result was unexpected, since the slow-release urea should

Table 2. Leaf chlorophyll content, stem diameter, ear insertion height and ear diameter of the maize hybrid Agroeste 1551 PRO 2, as a function of the protection mechanism and N dose, Santa Rosa do Sul - SC (2017/2018 summer crop).

\begin{tabular}{cccccc}
\hline & $\begin{array}{c}\text { Leaf } \\
\text { chlorophyll }\end{array}$ & $\begin{array}{c}\text { Stem } \\
\text { diameter } \\
(\mathbf{c m})\end{array}$ & $\begin{array}{c}\text { Ear } \\
\text { insertion } \\
\text { height } \\
(\mathbf{m})\end{array}$ & $\begin{array}{c}\text { Ear } \\
\text { diameter } \\
(\mathbf{c m})\end{array}$ & $\begin{array}{c}\text { Ear length } \\
(\mathbf{m m})\end{array}$ \\
\hline $\begin{array}{c}\text { Protection } \\
\text { Urease }\end{array}$ & $53.07^{\mathrm{ns}}$ & $21.01^{\mathrm{ns}}$ & $1.58^{\mathrm{ns}}$ & $43.38^{\mathrm{ns}}$ & $118.00^{\mathrm{ns}}$ \\
Nitrification & 52.11 & 20.90 & 1.58 & 44.24 & 118.00 \\
Slow-release urea & 51.54 & 20.32 & 1.51 & 43.92 & 123.00 \\
Conventional urea & 51.02 & 19.99 & 1.51 & 43.67 & 119.00 \\
\hline Dose (\%) & & & & & \\
0 & $48.59 \mathrm{~b}$ & $19.85^{\mathrm{ns}}$ & $1.53^{\mathrm{ns}}$ & $42.48^{\mathrm{ns}}$ & $110.50 \mathrm{~b}$ \\
25 & $50.59 \mathrm{ab}$ & 19.95 & 1.51 & 42.79 & $114.05 \mathrm{ab}$ \\
50 & $53.02 \mathrm{ab}$ & 21.13 & 1.57 & 44.75 & $123.72 \mathrm{ab}$ \\
75 & $53.72 \mathrm{a}$ & 20.72 & 1.55 & 44.36 & $123.62 \mathrm{ab}$ \\
100 & $53.75 \mathrm{a}$ & 21.12 & 1.56 & 44.64 & $127.65 \mathrm{a}$ \\
\hline $\mathrm{CV}(\%)$ & 8.22 & 7.77 & 4.86 & 4.70 & 9.82 \\
\hline
\end{tabular}

${ }^{n s}$ Not significant (ANOVA $\mathrm{p}<0.05$ ). Means followed by the same letter in the column do not differ from one another according to Tukey's test $(\mathrm{p}<0.05)$. 
Table 3. Yield components and productivity of the maize hybrid Agroeste 1551 PRO 2, as a function of the protection mechanism and N dose, Santa Rosa do Sul - SC (2017/2018 summer crop).

\begin{tabular}{lccccc}
\hline & $\begin{array}{c}\text { 1000-grain } \\
\text { weight (g) }\end{array}$ & $\begin{array}{c}\text { Kernels } \\
\text { per row }\end{array}$ & $\begin{array}{c}\text { Kernels } \\
\text { per ear }\end{array}$ & Rows per ear & $\begin{array}{c}\text { Productivity } \\
\text { kg ha }^{-1}\end{array}$ \\
\hline Protection & $265.82^{\text {ns }}$ & $26.8^{\text {ns }}$ & $381.30^{\text {ns }}$ & $14.21^{\text {ns }}$ & $6361.97 \mathrm{ab}$ \\
Urease & 260.79 & 26.61 & 384.92 & 14.44 & $5994.57 \mathrm{ab}$ \\
Nitrification & 262.95 & 27.30 & 395.47 & 14.43 & $5514.96 \mathrm{~b}$ \\
Slow-release urea & 264.88 & 27.26 & 391.77 & 14.36 & $6491.47 \mathrm{a}$ \\
Conventional urea & & & & & \\
\hline Dose (\%) & $237.87 \mathrm{c}$ & $25.13 \mathrm{~b}$ & $358.00 \mathrm{~b}$ & $14.24^{\text {ns }}$ & $4842.37 \mathrm{c}$ \\
0 & $253.76 \mathrm{bc}$ & $25.79 \mathrm{ab}$ & $368.93 \mathrm{ab}$ & 14.25 & $5503.56 \mathrm{bc}$ \\
25 & $271.56 \mathrm{ab}$ & $27.58 \mathrm{ab}$ & $398.15 \mathrm{ab}$ & 14.40 & $6341.56 \mathrm{bc}$ \\
50 & $267.93 \mathrm{bc}$ & $27.87 \mathrm{ab}$ & $400.63 \mathrm{ab}$ & 14.36 & $6461.65 \mathrm{ab}$ \\
75 & $286.93 \mathrm{a}$ & $28.58 \mathrm{a}$ & $415.90 \mathrm{a}$ & 14.53 & $7249.50 \mathrm{a}$ \\
\hline 100 & 8.78 & 9.44 & 10.70 & 2.34 & 14.73 \\
\hline CV (\%) & & & & & \\
\hline
\end{tabular}

${ }^{\mathrm{ns}}$ Not significant (ANOVA $\mathrm{p}<0.05$ ). Means followed by the same letter in the column do not differ from one another according to Tukey's test $(\mathrm{p}<0.05)$.

reduce the losses and increase the fertilization efficiency, as observed by Guareschi et al. (2013). The high temperatures and rainfall recorded throughout the experiment may have accelerated the capsule degradation and, consequently, the release of the element, considering that, after surface application, there were rains above $40 \mathrm{~mm}$ and a subsequent period of high soil moisture (Figure 1). In addition, the lime coating of the capsule may have increased $\mathrm{pH}$ around the granules, thus contributing to the formation of ammonia and losses by volatilization, which surpassed those detected with the application of conventional urea.

It was also expected that the urea with urease and nitrification inhibitors could result in higher fertilization efficiency, thus increasing productivity. However, what was found is what is reported in several studies, that is, increment in terms of productivity and yield components with 
the increase of the doses and with no influence of the protection mechanisms used (Soratto et al., 2011; Souza et al., 2011; Mota et al., 2015; Lima et al., 2018). Although the soil in the experimental area presents coarse texture and high $\mathrm{pH}$ (Table 1), condition in which the use of inhibitors is more significant (Abalos et al., 2014), there was no response.

\section{Conclusions}

Fertilizers with urease inhibitor, nitrification inhibitor and slow-release urea were not efficient in increasing maize productivity in relation to the conventional urea, in the edaphoclimatic conditions of the present study.

\section{References}

ABALOS, D.; JEFFERY, F.; SANZ-COBENAA, A.; GUARDIA. A. G.; VALLEJO, A. Metaanalysis of the effect of urease and nitrification inhibitors on crop productivity and nitrogen use efficiency. Agriculture, Ecosystems \& Environment, Amsterdam,v. 189, p.136-144, 2014. DOI: 10.1016/j.agee.2014.03.036.

AITA, C.; BALEM, A.; PUJOL, S.B.; SCHIRMANN, J.; GONZATTO, R.; GIACOMINI, D.A.; VARGAS, P.V.; GIACOMINI, S.J. Redução na velocidade da nitrificação no solo após aplicação de cama de aviário com dicianodiamida. Ciência Rural, Santa Maria, v. 43, n. 8, p. 1387-1392, 2013. DOI: $10.1590 / \mathrm{S} 0103-84782013005000102$.
ARGENTA, G.; SILVA, P.R.F.; BORTOLINI, C.G.Clorofila na folha como indicador do nível de nitrogênio em cereais. Ciência Rural, Santa Maria, v. 31, n. 4, p. 715-722, 2001. DOI: 10.1590/S0103-84782001000400027.

CIVARDI, E.A.; NETO, A.N.S.; RAGAGNIN, V.A.; GODOY, E.R.; BROD, E. Ureia de liberação lenta aplicada superficialmente e ureia comum incorporada ao solo no rendimento do milho. Pesquisa Agropecuária Tropical, Goiânia, v. 41, n. 1, p.52-59, 2011. DOI: 10.5216/pat.v41i1.8146.

FRAZÃO, J. J.; SILVA, A. R.; SILVA, V. L.; OLIVEIRA, V.A.; CORREA, R. S. Fertilizantes nitrogenados de eficiência aumentada e ureia na cultura do milho. Revista Brasileira de Engenharia Agrícola e Ambiental, Campina Grande, v. 18, n. 12, p.1262-1267, 2014. DOI:10.1590/1807-1929/agriambi. v18n12p1262-1267.

GANS, W.; HERBST, F.; MERBACH, W. Nitrogen balance in the system plant-soil after urea fertilization combined with urease inhibitors. Plant Soil Environment, Praga, v. 52, p.36-38, 2006.

GUARESCHI, R.F.; PERIN, A.; GAZOLLA, P.R. Produtividade de Milho Submetido a Aplicação de Ureia Revestida por Polímeros. Global Science and Technology, Rio Verde, v. 6 , n. 2, p.31-37, 2013. DOI: 10.14688/1984- 
3801.V06N02A04.

LANA, R.M.Q.; PEREIRA, V.J.; LEITE, C.N.; TEIXEIRA, G.M.; GOMES, J.S.; CAMARGO, R. NBPT (urease inhibitor) in the dynamics of ammonia volatilization. Revista Brasileira de Ciências Agrárias, Recife, v. 13, n. 2, p. 1-8, 2018. DOI: 10.5039/agraria.v13i2a5538.

LIMA, J. E. S.; NASCENTE, A. S.; SILVEIRA, P. M.; LEANDRO, W. M. Volatilização da amônia da ureia estabilizada com NBPT na adubação em cobertura da Urochloaruziziensis. Colloquium Agrariae, Goiânia, v. 14, n. 1, p.92-100, 2018. DOI: 10.5747/ca.2018.v14.n1.a193.

MALZER, G.L.; KELLING, K.A.; SCHMITT, M.A.; HOEFT, R.G.; RANDALL, G.W. Performance of dicyandiamide in the north central states. Communications in Soil Science and Plant Analysis, New York, v. 20, n. 19-20, p. 2001-2022, 1989.

MANUAL de calagem e adubação para os estados do Rio Grande do Sul e de Santa Catarina. 11. ed. Porto Alegre: Sociedade Brasileira de Ciência do Solo: Comissão de Química e Fertilidade do Solo - RS/SC, 2016. 376 p.

MORO, E.; CRUSCIOL, C.A.C.; NASCENTE, A.S.; CANTARELLA, H. Teor de nitrogênio inorgânico no solo em função de plantas de cobertura, fontes de nitrogênio e inibidor de nitrificação. Pesquisa Agropecuária Tropical,
Goiânia, v. 43, n. 4, p. 424-435, 2013. DOI: $10.1590 /$ S1983-40632013000400003.

MOTA，M.R.; SANGOI，L.; SCHENATTO, D.E.; GIORDANI, W.; BONIATTI, C.M.; DALL'IGNA, L. Fontes estabilizadas de nitrogênio como alternativa para aumentar o rendimento de grãos e a eficiência de uso do nitrogênio pelo milho. Revista Brasileira de Ciência do Solo, Viçosa, v. 39, n. 2, p. 512-522, 2015. DOI: 10.1590/01000683rbcs20140308.

RITCHIE, S. W.; HANWAY, J. J.; BENSON, G. O. How a corn plant develops? Ames: Iowa State University of Science and Technology, 1993. 21 p. (Special Reportn. 48).

SILVA, D. F.; PEGORARO, R. F.; MAIA, V. M.; KONDO, M. K.; SOUZA, G. L. O. D.; MOTA, M. F. C. Volatilização de amônia do solo após doses de ureia com inibidores de urease e nitrificação na cultura do abacaxi. Revista Ceres, Viçosa, v. 64, n. 3, p.327-335, 2017. DOI: 10.1590/0034$737 \times 201764030014$.

SOARES, J. R.; CANTARELLA, H; MENGUELE, M. L. C. Amonia volatilization losses from surface-applied urea with urease and nitrification inhibitors. Soil Biology and Biochemistry, v. 52, p.82-89, 2012. DOI: 10.1016/j.soilbio.2012.04.019.

SORATTO, R.P.; SILVA,A.H.;CARDOSO, S.M.; MENDONÇA, C.G. Doses e fontes alternativas 
de nitrogênio no milho sob plantio direto em solo arenoso. Ciência e Agrotecnologia, Lavras, v. 35, n. 1, p. 62-70, 2011. DOI: 10.1590/S141370542011000100007.

SOUZA, J.A.; BUZETTI, S.; TEIXEIRA FILHO, M.C.M.; ANDREOTTI, M.; SÁ, M.; E. de. Adubação nitrogenada na cultura do milho safrinha irrigado em plantio direto. Bragantia, Campinas, v. 70, n. 2, p.447-454, 2011. DOI: 10.1590/S0006-87052011000200028.

VALDERRAMA, M.; BUZETTI, S.; BENETT, C. G. S.; ANDREOTTI, M.; TEIXEIRA FILHO, M.C. M. Fontes e doses de NPK em milho irrigado sob plantio direto. Pesquisa Agropecuária Tropical, Goiânia, v. 41, n. 2, p.254-263, 2011. DOI: 10.5216/pat.v41i2.8390.
VALDERRAMA, M.; BUZETTI, S.; TEIXEIRA FILHO, M. C. M; BENETT, C. G. S.; ANDREOTTI, M. Adubação nitrogenada na cultura do milho com ureia revestida por diferentes fontes de polímeros. Semina: Ciências Agrárias, Londrina, v. 35, n. 2, p.659-670, 2014. DOI: $10.5433 / 1679-0359.2014 v 35 n 2 p 659$.

VARGAS, V.P.; SANGOI, L.; ERNANI, P.R.; SIEGA, E.; CARNIEL, G.; FERREIRA, M.A. Os atributos nas folhas são mais eficientes que o $\mathrm{N}$ mineral no solo para avaliar a disponibilidade desse nutriente para o milho. Bragantia, Campinas, v. 71 , n. 2 , p. $245-255$, 2012. DOI: 10.1590/S0006-87052012000200014. 